\title{
PENGEMBANGAN MODEL LATIHAN PASSING ATAS BOLAVOLI DI SMK AL HUDA WAJAK MALANG
}

\author{
Yuskhil Mushofi \\ IKIP Budi Utomo Malang \\ Email: yuskhilgalbina@gmail.com
}

\begin{abstract}
ABSTRAK
Tujuan penelitian pengembangan ini adalah mengembangkan model latihan passing atas pada siswa peserta bolavoli putra di SMK Al-Huda Wajak Malang. Metode yang digunakan dalam penelitian ini adalah penelitian pengembangan. Pengumpulan data dilakukan dengan menggunakan angket untuk ahli materi dan pedagogik, serta guru dengan kualifikasi meliputi satu ahli materi dan pedagogik, guru Pendidikan Jasmani Olahraga dan Kesehatan SMK Al-Huda Wajak Malang untuk melakukan uji coba kelompok kecil (tahap I) sebanyak 10 siswa dan uji coba kelompok besar (tahap II) sebanyak 20 siswa. Hasil penelitian ini diperoleh hasil validasi ahli materi dan pedagogik untuk kelayakan produk awal diperoleh prosentase sebesar $88,89 \%$ dengan kriteria baik yang berarti layak digunakan. Hasil uji coba kelompok kecil (tahap I) adalah 96,81\% dengan kriteria sangat baik yang berarti sangat layak digunakan. Kemudian, untuk hasil uji coba kelompok besar (tahap II) adalah 97,77\% dengan kriteria sangat baik yang berarti sangat layak digunakan.
\end{abstract}

Kata Kunci: Pengembangan, Model latihan, Passing Atas, Bola Voli

\begin{abstract}
The purpose of this development research is to develop a model of upper passing training for male volleyball participant students at Al-Huda Wajak Vocational School Malang. The method used in this research is development research. Data collection was carried out using questionnaires for material and pedagogical experts, and teachers with qualifications included one material and pedagogic expert, teacher of Physical Education in Sport and Health of Al-Huda Wajak Vocational High School Malang to conduct small group trials (stage I) of 10 students and test try large groups (stage II) as many as 20 students. The results of this study obtained the results of the validation of material and pedagogic experts for the feasibility of the initial product obtained by a percentage of $88.89 \%$ with good criteria which means it is worthy of use. The results of the small group trial (stage I) are $96.81 \%$ with very good criteria which means it is very feasible to use. Then, for the results of a large group trial (stage II) it is $97.77 \%$ with very good criteria which means it is very feasible to use.
\end{abstract}

Keywords: Development, Model exercises, Passing Up, Volleyball 


\section{PENDAHULUAN}

Permainan bola voli adalah permainan yang dimainkan oleh dua regu yang masing-masing regu berjumlah enam orang, tujuan utama dalam permainan ini adalah memukul bola kebidang lapangan lawan sehingga lawan tidak bisa mengembalikan bola. (M. Riza Pranopik, 2017). Untuk mendukung pukulan tersebut maka diperlukan teknik dasar passing bawah dan passing atas yang baik, terutama passing atas karena banyak digunakan untuk mengumpan bola untuk dipukul kebidang lawan.

Menurut Suharno dalam (Budiwanto, 2004) Teknik adalah suatu proses gerakan dan pembuktian dalam praktek dengan sebaik mungkin untuk menyelesaikan tugas yang pasti dalam cabang olahraga. Dalam mempertinggi prestasi bolavoli, teknik ini erat hubungannya dengan kemampuan gerak, kondisi fisik, taktik dan mental. Teknik dasar bolavoli harus betul-betul dikuasai terlebih dahulu guna dapat mengembangkan mutu prestasi permainan bolavoli. Penguasaan teknik dasar permainan bolavoli merupakan salah satu unsur yang ikut menentukan menang atau kalahnya suatu regu di dalam suatu pertandingan di samping unsur-unsur kondisi fisik, taktik, dan mental.Adapun teknik-teknik dasar permainan bolavoli menurut sistematikanya adalah sebagai berikut, (a) Teknik dasar passing atas, (b) Teknik passing bawah, (c) Set-up/umpan, (d) Spike/smash, (e) Servis, (f) Block/bendungan.

Menurut (M Taufiq Hidayat, 2015) penguasaan teknik dasar bola voli terdiri dari antara lain: servis, passing, smash dan block, dari berbagai macam teknik dasar tersebut yang tidak bias diabaikan adalah passing bawah dan passing atas. Dengan melakukan passing yang baik dalam suatu permainan maka strategi bertahan dan menyerang yang diharapkan dapat dilakukan dengan sebaik-baiknya.(P. SatyaHusmara, 2017)

Menurut Samsudin dikutip dari (Asmuri, 2007) Jenis Passing dalam permainan bola voli ada dua macam yaitu passing bawah dan passing atas. Passing bawah dalam permainan bola voli pada umumnya passing dari atas yang tidak melibatkan jari-jari dan bola menyentuh bagian di atas pergelangan tangan, sedangkan passing atas adalah bola yang diumpan dari atas umumnya melibatkan jari-jari tangan. Passing atas harus dikuasai dengan baik, karena passing atas digunakan untuk mengumpan bola yang kemudian dilakukan pukulan kedaerah lawan untuk menghasilkan point. Menurut (Depdiknas,2005) "pengembangan pembelajaran merupakan suatu wadah untuk menyalurkan minat dan mengembangkan bakat dan kreativitas siswa pada satu atau beberapa kegiatan tertentu".

Kondisi belajar siswa pada kegiatan pengembangan, berbeda dengan kondisi belajar siswa pada saat mengikuti mata pelajaran bolavoli.Pada kegiatan pembelajaran siswa tidak terikat dengan waktu jam mata pelajaran lain, 
waktu pelaksanaan leluasa untuk diatur karena hanya terpusat pada satu kegiatan, dan sangat memungkinkan untuk berkembangnya prestasi kegiatan pembelajaran pada cabang bolavolidi SMK Al-Huda Wajak Malang.

Pembinaan prestasi awal diperkenalkan teknik dasar permainan bolavoli yaitu teknik passingatas, dalam pengenalan teknik dasar passingatas, pertama tangan kanan dan tangan seperti memegang mangkok. Kedua tanggan di angkat persis berada di atas kening. Tangan diangkat lurus tidak ditekuk baik itu sebelum datangnya bola, saat perkenan dengan bola dan sesudah perkenaan dengan bola. Gerakan kedua lengan dari bawah ke atas dan berporos pada bahu. Apabila datangnya bola dari depan maka ibu jari lurus berada di depan kening, jika akan melakukan passing atas posisi kaki di tekuk dan badan lurus dan kedua tanggan di angkat sejajar dengan kening ataulebih tinggi. Bagian perkenaan tanggan dengan bola yaitu pada bagian kedua jari tangan bagian atas lurus seperti memegang mangkok. Saat perkenaan bola, posisi bola tidak berada di bawa kening, karena semakin rendah posisi bola saat perkenaan maka hasil perkenaan bola kurang maksimal, tinggi bola menentukan hasil passing atas yang lebih baik.dan bila makin tinggi lagi maka pantulan bola akan mengarah ke belakang. Saatmelakukan passing bola di depan maka kedua kaki di bukak dan ditekuk supaya keseimbangan lebih akurat, saat perkenaan dengan bola kedua kaki di tekuk.

Hasil observasi awal melalui metode pengamatan yang dilakukan peneliti yang ditujukan untuk pelatih Mengembangkan latihan bolavoli dan siswa peserta bolavoli, banyak siswa mengalami kesulitan dalam melakukan passing atas. Hal ini dapat dilihat dari hasil passing atas yang tidak menemui sasaran saat bermainbolavoli diSMK Al-Huda Wajak Malang melakukan latihan passing atas serta materi latihan passing atas yang dilakukan pelatih kurang menarik. Variasi latihan passing atas tidak dilakukan secara efektif dan kompleks, jarang sekali siswa baik secara individu atau tim diberi latihan khusus dari bentuk-bentuk latihan passing atas.Keterampilan yang kurang dimiliki oleh siswa diantaranya adalah, posisi badan saat melakukan passing masih kurang tepat, hampir $80 \%$ posisi badan masih salah, keterampilan lain adalah perkenaan bola, hampir $86,6 \%$ juga kurang tepat, banyak perkenaan bola saat passing mengenai bola bagian samping, hal ini mengakibatkan hasil passing tidak tepat sasaran, keterampilan yang lain adalah gerakan kedua jari tangan, 73,3\% gerakan jari tanggan saat melakukan passing masih kurang tepat, untuk menghasilkan passing yang bagus peserta masih kurang membuka kedua jari tanggannya saat passing, keterampilan selanjutnya adalah posisi kaki, 93\% posisi kaki masih banyak yang kurang tepat, keterampilan berikutnya adalah pandangan mata, $86 \%$ lebih siswa peserta Bolavoli SMK Al-Huda Wajak Malang saat melakukan passing masih 
terfokus pada bola, hal ini menyebabkan pemain tidak bisa memilih sasaran yang akan di tuju, padahal saat melakukan passing pemain harus terfokus pada sasaran.

Sedangkan analisis kebutuhan yang menggunakan metode kuisioner diketahui $75 \%$ siswa peserta bolavoli jarang mendapatkan model latihan passing atas selama mengikuti kegiatan bolavoli di SMK Al-Huda Wajak Malang dan100\% siswa peserta bolavoli setuju dengan adanya pengembangan model latihan passing atas bolavoli. Sedangkan siswa peserta bolavoli di SMK Al-Huda Wajak Malang kurang memiliki penguasaan teknik passing atas dan bersedia jika dikembangkan model latihan passing atas bola voli di SMK Al-Huda Wajak Malang.

Berdasarkan latar belakang diatas peneliti ingin berusaha mengembangkan model latihan passing atas. Diharapkan dengan adanya model latihan teknik dasar passing atas ini bisa dijadikan bahan dan media alternatif model latihan passing atas. Untuk itu dilakukan penelitian dengan judul "Pengembangan Model Latihan Passing Atas Bolavoli di SMK AlHuda WajakMalang"

\section{METODE}

Dalam pengembangan ini, peneliti menggunakan model pengembangan (research and development) (Borg dan Gall, 1983) yang terdiri dari sepuluh langkah sebagai berikut,(1) Melakukan penelitian dan pengumpulan informasi (kajian pus- taka, pengamatan kelas, persiapan laporan pokok persoalan). (2) Melakukan perencanaan (pendefinisian keterampilan, perumusan tujuan, penentuan urutan pengajaran, dan uji coba skala kecil). (3) Mengembangkan bentuk produk awal (penyiapan materi pengaja- ran, penyusunan buku pegangan, dan perlengkapan evaluasi) (4) Melakukan uji lapangan permulaan (dilakukan pada 2-3 sekolah, menggunakan 6-12 subyek). (5) Melakukan revisi terhadap produk utama (sesuai dengan saran-saran dari hasil uji lapangan permulaan). (6) Melakukan uji lapangan utama (dengan 5-15 sekolah dengan 30-100 subyek. (7) Melakukan revisi produk (berdasarkan saran-saran dan hasil uji coba lapangan utama). (8) Uji lapangan meliputi 10-30 sekolah dengan 40-60 subyek. (9) Revisi produk akhir. (10) Membuat laporan mengenai produk pada jurnal, bekerja dengan penerbit yang dapat melakukan distribusi secara komersial.

Prosedur pengembangan yang telah dikemukakan di atas tentu saja bukan merupakan langkah-langkah baku yang harus diikuti secara kaku. Pengembangan produk dalam penelitian pengembangan dilakukan berdasarkan data hasil analisis kebutuhan lapangan (Winarno, 2011). 


\section{HASIL DAN PEMBAHASAN}

Pada hasil pengembangan ini akan disajikan data tentang tanggapan (1) Analisis kebutuhan (2) ahli kepelatihan, (3) ahli pembelajaran, (4) guru mata pelajaran penjaskes. Untuk mendapatkan data uji coba tahap I dan II, peneliti menggunakan metode pengumpulan data berupa kuesioner untuk (1) uji coba tahap I sebanyak 10 pemain , (2) uji coba tahap II sebanyak 20 pemain, dan untuk data evaluasi berupa kuesioner untuk 3 ahli, yaitu (1) ahli kepelatihan sebanyak 2 orang, dan (2) ahli pembelajaran sebanyak 1 orang. Pada pengembangan model latihan passing ini teknik yang digunakan untuk mengolah data hasil penelitian dari ahli bolavoli dan ahli pembelajaran serta peserta bolavolidi SMK Al-Huda Wajak Malangsebagai subjek uji coba adalah teknik persentase yang diperoleh dari data hasil uji coba. Dan selanjutkan akan digunakan untuk evaluasi.

Pembahasan dari hasil penelitian iniBerdasarkan data yang berhasil dikumpulkan dari ahli bolavoli, ahli pembelajaran, dan pesertabolavoli di SMK Al-Huda Wajak Malang pada saat uji coba tahap I dan II, maka ada beberapa produk yang perlu direvisi. Hal ini dilakukan untuk lebih mengoptimalkan manfaat model latihan passing yang dikembangkan.

Ringkasan revisi berdasarkan masukan dan saran dari ahli bola voli, ahli kepelatihan dan pemain bola voli di SMK Al-Huda Wajak malang adalah sebagai berikut: 1 . Pelambung harus baik, supaya hasil sesuai dengan yang diinginkan, 2. Keranjang lebih ditinggikan $15 \mathrm{~cm}$, 3.Pada saat latihan lebih baik sasaran bisa lebih dari satu, 4.Pada saat latihan petak jangan terlalu ketepi, sehingga bola cenderung keluar, lebih baik digeser $30 \mathrm{~cm}$ kedalam lapangan. Lebih baik kecepatan bola server semakin lama semakin meningkat

\section{KESIMPULAN}

Kesimpulan penelitian pengembangan model latihan passing atas pada peserta bola voli di SMK Al-Huda Wajak Malang pada bagian "Pengorganisasian Kelas/Langkah-langkah Pembelajaran" dan "Penilaian Pembelajaran" dalam bentuk buku sudah sangat layak digunakan dengan criteria sangatbaik sehingga Buku tersebut dapat digunakan sebagai pedoman pembelajaran oleh guru dan siswa. Kedepan semoga ada penelitian lainyang lebih mendalam tentang passing atas pada permainan bola voli agar tercipta banyak referensi yang bisa digunakan untuk proses pembelajaran.

\section{DAFTAR PUSTAKA}

Asmuri, 2013.Pembelajaran Passing atas dengan bola karet pada siswa SDN 11 Tanjung BuluhKab. Sambas 
Budiwanto, S. 2004. Pengetahuan dasar melatih Olahraga. Malang: Depdiknas Universitas Negeri Malang

M. Riza Pranopik. 2017. Pengembangan variasi latihan smash bolavoli

M TaufiqHidayat. 2015.Peningkatan kemampuan passing bawah dalam permainan bola voli melalui latihan passing bawah duduk berdiri pada bangku dan passing bawah dengan berjalan pada siswa kelas VI SDN Tanggul wetan 01 Jember

Departemen Pendidikan Nasional. Direktorat Jenderal PMPTK. 2009. Pengembangan Bahan Ajar (Modul). Bahan TOT Calon Pengawas dan Kepala Sekolah. Jakarta: Depdiknas

Winarno, M.E. 2010. Metodologi Penelitian Pendidikan Jasmani, Program Pasca Sarjana, IKIP Budi Utomo Malang. 